\title{
Economic Indicators in United Arab Emirates: Assessing the Sustainability of the Country's Economic Performance
}

\author{
Ghassan Ossman
}

School of Business Administration, Al Dar University College, United Arab Emirates

Copyright $\bigcirc 2016$ by authors, all rights reserved. Authors agree that this article remains permanently open access under the terms of the Creative Commons Attribution License 4.0 International License

\begin{abstract}
The study determines the influence of indicators of economic growth in the United Arab Emirates to assess the sustainability of the country's economic performance. It focuses on three economic indicators; rates of unemployment, inflation, and population growth and their influence on the UAE economic performance sustainability, and determines how strongly these three variables can predict such sustainability. The study identifies both a significant difference in the level of UAE economic performance in the past ten years and the long-run, as well as the independence of economic indicators from sustainability of economic performance of the nation. Findings of the study show that decline in inflation rates of the national economy fosters financial stability and inflation rates remained low within acceptable levels in the previous years and will continue to maintain stability in the next future period, five to ten years. The country is projected to witness population growth as the nation becomes a preferred destination for living, promising job opportunities, and local and foreign investments. UAE economy is experiencing growth in economic performance and expected to maintain stability in the coming years with the government efforts to achieve long-term development objectives for year 2021. Stability remains the hallmark of the nation economic activity with a continuous focus on infrastructure projects as growth of various industries, improvements in real estate industry, tourism, and rising growth in economic performance will allow UAE to achieve sustainability in economic performance. Correlation analysis reveals that the variable of unemployment rates has no significant influence on economic performance sustainability which implies that, for the last ten years, the country experienced economic growth

growth will lead to changes in the level of economic performance sustainability. The correlation coefficient of -0.631 reveals high negative correlation between population growth and economic performance sustainability which indicates that increases in population growth over the last ten years in the country, has led to decreases in economic performance sustainability. The T-test analysis for significant difference of UAE economic performance in the last ten years and over the long-run result in acceptance of the null hypothesis indicates that the two periods are just the same. The rising trend of UAE economic performance in the past ten years will continue over the long-run. Economic indicators variables; unemployment, inflation, and population growth rates are positively related and strong predictors of economic performance sustainability. Chi-Square Test of Independence results in acceptance of null hypothesis. Economic indicators and sustainability of economic performance are not independent of each other which implies that changes in the rates of economic indicators variables of unemployment, inflation, and population growth will cause a change in the sustainability of economic performance. Recommendations of the study include the conduct of further studies focusing on variables not included in the study that are likely to influence the level of economic performance, monitor the level of population growth which is significantly correlated with economic performance, develop other economic models that will determine an increase in a nation's economic performance and achieve sustainability in the long-run, and the formulation of economic policies and strategies to overcome significant long-term challenges on oil dependence, growing expatriate workforce, and inflationary pressures.
\end{abstract} and was not influenced by variations in unemployment levels. Similarly, the variable of inflation rates shows no significant influence on economic performance at both $5 \%$ and $10 \%$ significance level which implies that, for the last ten years, the country experienced economic growth and was not influenced by variations in inflation rates in the country. T-test shows significant relationship between population growth rates and economic performance sustainability at $5 \%$ level of significance, a change in the level of population
Keywords Economic Performance, Unemployment, Inflation, Population Growth

\section{Introduction}

The study determines the influence of economic indicators 
in UAE on sustainability of economic performance. It identifies economic indicators that will predict economic performance sustainability of the country. It focuses on the variables of unemployment, inflation, and population growth rates. Significant difference in the level of economic performance over the past ten years and in the long-run is determined as well as independence of the economic indicators from economic performance sustainability. The study will provide insights to the UAE policy makers, for enhancement of policies through emphasis on the latest economic indicators that influence the performance of the nation. It will serve as a guide to students in understanding the different factors currently affecting the performance of UAE economy which can in turn influence the standard of living of the people in the country. Researchers may use the data of the economic indicators that are relevant to the performance of UAE economy as well as of other nations.

Economic indicators are data which can be used to interpret current or future investment possibilities and provide measurements for the evaluation of the health of a nation's economy. Economists employ economic indicators to determine the performance level of an economy against economic objectives. Tracking of these indicators is valuable to evaluate economic improvement or deterioration and can provide the basis for government intervention in terms of policy formulation and implementation.

The positive characteristics of UAE economy, attractiveness of the investment climate, and stability of the financial and fiscal sectors, contributed to the strong growth rates of the country, Ossman [19]. Being the second largest economy in the Arab region, UAE has advanced position in terms of development and competitiveness in the global economy. The economy is characterized by sizable annual trade surplus, high per capita income, and increased government spending on infrastructure, job creation, and promotion of private sector involvement. In 2009, the government resorted to strategies of increased government spending and boosting liquidity in the banking industry to overcome tight international credit, global financial crisis, and deflated asset prices. The economy achieved substantial economic performance and stability in year 2012 with a diversification process driven by foreign trade, recovery in the tourism industry, real estate and construction industry, and other non-oil sectors. Oil and non-oil sectors contributed to UAE GDP growth rate of $4.6 \%$ reaching 1025.6 billion AE Dirham during the year representing $67.3 \%$ of the country GDP.

The country is projected to experience stronger growth rates in the next future period, based on significant economic and development indicators in the previous years. Greater progress in the country is attributed to stability of economic and political conditions, low inflation rates, and advanced infrastructure which attracts foreign investment and capital, Ossman [18]. In terms of national economy strength, UAE Economy [33], reports that UAE economic performance maintained its strength over the years, despite global crisis, due to the government efforts to achieve growth and attract foreign investments. The nation's commitment for growth expansion and reduction of dependence on oil resources contributes to economic progress and global competitiveness. Strategic plan of UAE in the next future period emphasizes diversification and the creation of opportunities through increased employment in the private sector and quality education. Significant long-term challenges of the country include its dependence on oil, growing inflation pressures and expatriate workforce, and achievement of sustainability in economic performance.

\subsection{Statement of the Problem}

This study determines the influence of economic indicators in United Arab Emirates on sustainability of economic performance. Specifically, it seeks answers to the following questions:

1. Is there significant influence of economic indicators in United Arab Emirates on sustainability of economic performance?

2. Is there significant difference in the level of economic performance of United Arab Emirates in the past ten years and in the long-run?

3. How strongly the economic indicators predict economic performance sustainability of United Arab Emirates?

4. Are economic indicators in United Arab Emirates independent of economic performance sustainability?

\subsection{Null Hypotheses}

Ho1: There is no significant impact of the macroeconomic indicators in United Arab Emirates on sustainability of economic performance.

Ho2: There is no significant difference in the level of economic performance of United Arab Emirates over the past ten years and in the long-run.

Ho3: The variables of unemployment rates, inflation rates and population growth rates do not predict economic performance of United Arab Emirates.

Ho4: Economic indicators in United Arab Emirates are not independent of economic performance sustainability.

\section{Literature Review and Studies}

Economic growth is the increase in an economy's total production of goods and services over a period of time, measured as the percent rate of increase in real GDP that results in improvement of quality of life of the people. It is associated with advances in technology, improvement in the literacy level and in the quality of life of the people and increase in capital stock. It occurs when an economy employs new technology, allows specialization through division of labor, discovers new resources, introduces new production methods, and increases the size of its working population. Depending on the nature of economic growth, a 
nation can experience potential costs such as account deficit, inflation, widening inequality, and environmental costs. Economic growth can occur without inflation if the growth of the aggregate demand is sustainable and balanced. Country Report [6], discusses the factors of rigid monetary policy and fixed exchange rates that hinder economic growth in UAE. Continuous high levels of profits from oil revenues can help the country avoid the trade-off between rapid growth and inflation. The Harrod-Domar Model of Economic Growth concludes that the economic system is at best balanced on a knife-edge of equilibrium growth even for the long-run, Solow [26]. As key parameters of labor force rate increase, capital output ratio and savings ratio slightly slip from dead center, the consequence is either prolonged inflation or growing unemployment. The absence of technological change influences natural rate of growth and labor force increase, and warranted rate of growth depends on investment saving habits of households and firms.

Unemployment rate measures the number of people seeking for jobs as a percentage of the total labor force. High rates of unemployment result in lower spending by consumers and will have negative effects on gross domestic product, housing markets, and retail stores. Government debt can increase in terms of assistance programs and stimulus spending. Unemployment rate indicates the labor-market health state of any country, explained by a framework of economic theory, imposing heavy costs on labor force in society, affect the levels of inflation, interest and exchange rates and aggregate demand and supply in the economy, Ossman [20].

Sherif [23] analyzed the unique unemployment anomaly in UAE and formulated a strategic policy to effectively combat the high rates of unemployment among UAE citizens. The policy is a federal plan of action for human resources development designed to reduce unemployment through stimulation of economic growth, increased productivity, educational system reforms, capital accumulation, skills development, and provision of skills consistent with labor market demands. Limitations of the research include the setting of priorities to ensure that implementation of each element of the strategy is cost effective. Findings reveal that complete implementation of the strategy is an effective solution to the unemployment problem in the country. The research offers a long-term practical solution to the problem of unemployment. The economic failure of the Arab region is to reduce unemployment due to the increase of labor force, low labor content of economic growth, inadequate macroeconomic policies, and rigid formal labor markets, registered during the period of 2000s, Bchir \& Rajhi [4]. A development framework to solve the problem will be judged on the short term capacity to reduce unemployment problem and ease of social tensions. The paper proposed short term reforms to accelerate job creation and allow the government to formulate a development model and initiate long term reforms. The proposed policies include improvement of labor impacts of macroeconomic policies, implementation of social VAT mechanism, reinforcement of migration policy, and reforms on public employment services. A Global Computable General Equilibrium Model was used to assess the economic impacts of the reforms showing variations of impacts across nations and the relevance of regional integration and public employment modernization in the Arab region.

The research of Bean and Pissarides [5] proved the cross-country bivariate correlation between unemployment and growth depending on economic structures across nations, utilizing a framework that incorporates matching frictions in the labor market and technology. The research presented a two-sector variant of the model showing imperfect competition in the consumption and production of goods. Findings show that expansion in market size for goods production and increased employment can result from a reduction in the propensity to save. Large expansion in employment can produce increased volume of saving if goods production entry costs are sufficiently large. Manchin and Manning [15] reviewed the causes and consequences of long-term unemployment in European labor markets. Both concluded that a collapse of outflow rates at all durations of unemployment results from the rise of long-term unemployment. Findings suggest that long-term unemployment is not a problem independent of unemployment itself, and is a horrid one for those unfortunate enough to experience it. Al-Habees and Abu Rumman [1] recognize that unemployment is a negative phenomenon in society adversely affecting the economy in different dimensions and directions, and showing imbalance in economic activity. It is considered as economic defect that influences community structure and economic growth, and indicates the size of labor employment as a human force associated with success factors related to economic growth. Their study focused on the relationship between growth of the economy and change of unemployment rates in Jordan and the effectiveness of economic policies to reduce unemployment rates in Arab countries.

Inflation reflects an increase in the cost of essential goods and services. High rate of inflation leads to decline in the average standard of living, decrease in the purchasing power of consumers, and decrease in the employment rate. However, moderate levels of inflation encourage both investment due to moderate level of interest rates, and consumer spending. Inflation refers to broad increase in the prices of goods and services in any economy over a sustained period of time and is erosion to the economy's currency value, Simpson [25]. A nation can plan for inflation and act accordingly. Unexpected high inflation tends to hurt workers, savers, and recipients of fixed incomes but often benefits business organizations through raise of prices without the need to raise wages. Periods of inflation tend to redirect investment from businesses and can cause problems in an economy as business organizations prefer less investments for long-term projects and less time in engaging for productive activities. The Phillips curve highlights the reason why high unemployment is undesirable and full employment is neither practical nor desirable. A variety of 
factors can alter the curve such as productivity gains, neither zero unemployment nor zero inflation scenario is viable in the long run. As technology progresses, structural employment becomes a recurrent problem, where workers find their skills no longer matching employers' needs and requires training update with the adoption of new technology. UAE Annual Economic Report [31] defines inflation as the percentage change in the value of the Whole Price Index on a year-on-year basis which measures the change in the prices of goods and services in a year. Changes in the cost of production and distribution, imbalance between demand and supply of money, or increase on products' taxes can cause inflation in the economy. The value of currency is reduced when an economy experiences inflation and the price level of goods and services rises. Consumers will experience difficulty in the purchase of basic commodities and will demand for higher incomes, hence, the government strives to keep inflation under control and achieve a limited inflation level, beneficial to the economy as it encourages borrowing and purchases of goods and services.

The UAE population is essentially small, Ibrahim \& Hellyer [13]. The combination of massive inward expatriates and high increase of the nation indigenous population contributed to the rapid population growth in recent years. The population at present is growing at a rapid rate attributed to the booming economy and the government support for large families of UAE nationals. Total population of UAE comprises of fifteen to twenty percent citizens and the rest is formed by foreign nationals from countries of Jordan, Egypt, Oman, Yemen, India, Afghanistan, Iran, Philippines, Palestine, and Europe. The UAE population is mostly urban in nature, and projected to grow to 7.9 million by 2020 at an average growth of $2.3 \%$ from 2010-2020, and with city dwellers to account for $86.7 \%$ of the nation's population by 2020, Everington [10].

The research study of Barlow [3] supports the position that slower population growth does not cause faster economic development. Analysis of the data from eighty six countries show that lagged fertility is added to the current rate of population growth as a predictor of the growth rate of per capita income. Findings reveal that the three-variable model shows negative relationship between per capita income growth and current growth of population and positive relationship with lagged fertility. In the case of Philippine economy, long-term equilibrium relationship is established between economic performance and population growth, Furuoka [11] indicating unidirectional causality from economic development to growth in population. Economic development in the country with positive impact on population growth supports the hypothesis of population growth, induced by economic development and increasing level of economic performance. The cross-country comparison of changes in per capita income and population variables conducted by Simon and Gobin [24] revealed that more people mean better economic performance. Analysis of the study show that higher density population implies faster growth in the economy in less developed countries and the relationship is statistically significant. Positive effect of population density implies that population growth has a positive effect on per capita income over the long-term.

\subsection{Theoretical Framework of the Study}

As presented in Figure 1, economic growth is shown as a cycle with complex chain of events, reinforced through a feedback to represent the long-term expansion of the productive potential of a country. The vicious circle of economic growth emphasizes the key drivers of growth and the factors that determine the long-run increases of a nation's Gross Domestic Product, which includes higher output, increased investment, higher productivity, increased wages, and rising consumer demand. Each factor varies in importance for a nation at a given point in time. Increased consumer demand will lead to higher output that results in increased investment. The model presents the advantages of economic growth in terms of higher standards of living, generation of more jobs that facilitates entry into the labor market, and fiscal dividend that will provide the government capability for improvement in public services and budget deficit reduction. The framework focuses on rising consumer demand and output that encourage investment to sustain economic growth through increased long-run aggregate supply. Economic growth is viewed as having positive impact on consumer and business confidence that promote consumer purchases. The cycle is expected to continue in the direction of the momentum until an external factor will intervene.

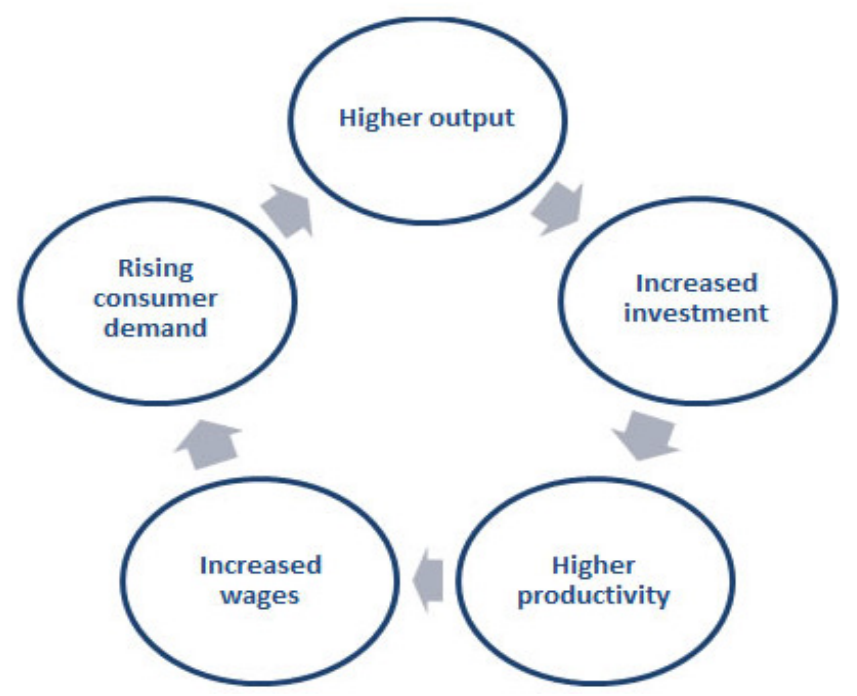

Figure 1. Theoretical Framework of the Study "Circle of Economic Growth" [7]

\subsection{Conceptual Framework of the Study}


Independent Variables

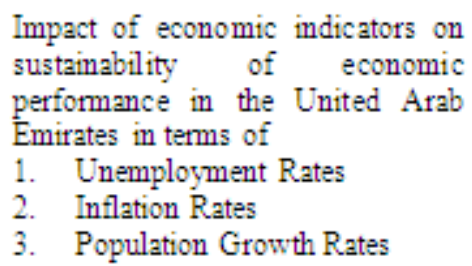

\section{Dependent Variable}
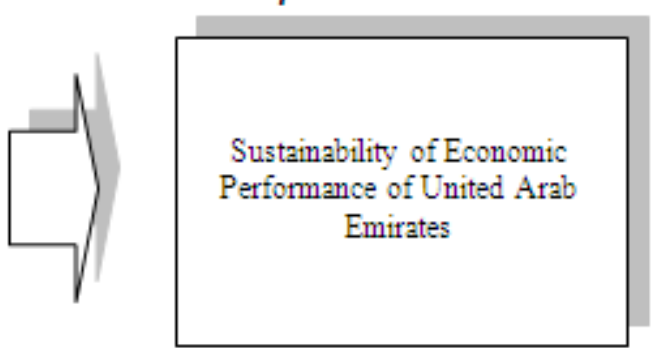

Figure 2. Conceptual Framework of the Study "Causal Relationship of Independent and Dependent Variables"

A cause and effect relationship is used in the study to indicate the influence of the independent variables on the dependent variable. As shown in figure 2, the study adopts the notion that economic indicators of unemployment, inflation, and population growth rates will influence the achievement of a sustainable economic performance in UAE over the long-run. The study focused on determining the relationship between economic indicators and economic performance to project its sustainability over the long-term.

\section{Methodology}

\subsection{Research Design}

The research is qualitative, quantitative and descriptive in nature, using both descriptive and inferential statistics to analyze data pertaining to the rates of unemployment, inflation, and population growth. Qualitative research is utilized and data analysis involved the search for patterns and features aimed at forming contextual descriptions of the variables of unemployment, inflation, and population growth. Quantitative data were collected based on precise measurements utilizing archival data sources and analysis, involved the establishment of statistical relationships.

The research study involves a documentary analysis of the data on economic indicators of unemployment, inflation, and population growth, and their impact on economic performance. Historical research and content analysis used as methods of research which involved the critical investigation of developments of the past and interpretation of the weighted evidence. The researcher interprets and evaluates the data for validity. Documentary analysis is used as descriptive research to explain the status of phenomenon at a period of time and its development over time. The researcher reviews and analyzes annual reports, brochures, office records available, and government manuals and standards to provide explanations of the issues raised by this study.

\subsection{Research Instruments and Techniques}

Statistical Treatment of Data

The study utilizes Pearson Correlation to measure the degree of influence of the economic indicators on economic performance of UAE. T-test is used to determine the significant difference between the economic performance of UAE over the past ten years and over the long-term. To assess the relationship between macroeconomic indicators with UAE's economic performance, and to determine degree to which the macroeconomic indicators predict the economic performance of the country, Multiple Regression Analysis is employed. Chi-Square Test determined categorical variables of economic indicators and economic performance are independent of each other.

\section{Results and Discussions}

\subsection{Status of Economic Indicators in UAE in Terms Of Unemployment, Inflation, and Population Growth Rates}

\subsubsection{UAE Unemployment Rate}

Unemployment rate in UAE measures the number of people actively looking for a job as a percentage of the labor force which averaged 3.12\% from year 1985 until year 2012, Trading Economics [28]. As presented in Figure 3, it has an all time high record of $4.6 \%$ in year 2011 and a low record of $3.1 \%$ in year 2005 . Unemployment Rate decreased to $4.20 \%$ in year 2012 from $4.60 \%$ in year 2011 . Unemployment rate reached $4.24 \%$ in year 2013 and is predicted to converge to 2.43 in the long-term, IECONOMICS [12].

Using autoregressive moving average model, forecasts for UAE Unemployment Rate are projected. Unemployment rate was $4.4 \%$ by the end of year 2015 , and expected to trend around $4.10 \%$ in year $2020,4.69 \%$ in year 2030 and $4.8 \%$ in year 2050 .

\section{UNEMPLOYMENT RATE}

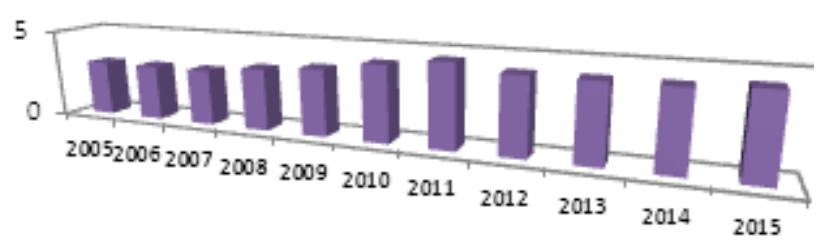

Figure 3. UAE Unemployment Rates (2005 - 2015) 
As presented in figure 3, the unemployment rate of UAE has slightly increased from $4.2 \%$ in year 2010 to $4.6 \%$ in year 2011. Estimates indicate high rates of economically active population in 2011 by $65.9 \%$ against $65.2 \%$ in 2010 . Development plans and policies were designed by the government to regulate labor markets and address unemployment among the UAE citizens, UAE Annual Economic Report [32]. The comprehensive population policy addressed population imbalance, focusing on Emiratization and development of optimal labor market organization.

WAM Emirates News Agency [34], reports the commitment of the UAE government through the Emirates National Development Programme to significantly reduce unemployment rates by 2021. To achieve this goal, $21^{\text {st }}$ Century skills will be embedded in the education system of the country, aiming to reduce unemployment rate to less than $1 \%$. Government strategies include promotion of private sector employment to Emirati nationals in areas of education, construction, logistics, and healthcare. Efforts to reduce unemployment rates have been successful to date, with unemployment rates falling to an average of $3.8 \%$ over the last ten years.

\subsubsection{UAE Inflation Rate}

Inflation rate in UAE records an average of $2.26 \%$ from year 1990 until year 2015, to reach an all time high of $12.3 \%$ in 2008 and a low record of $0.88 \%$ in 2011, Trading Economics [29]. Inflation rate in the country was recorded at $4.2 \%$ in June, $2015,4.3 \%$ in July 2015 , and is predicted to converge to $5.24 \%$ at the end of the year. Figure 4 presents the UAE inflation rates from 2005 to 2015 .

The inflation rates record stability in previous years in the aftermath of the financial crisis, with a rate $0.67 \%$ in 2012 compared to $0.88 \%$ in 2011 . The decline in inflation rates in the national economy fosters financial stability allowing the country to remain as an investment destination in the global business environment. Effectiveness of the UAE economic and fiscal policies enabled the economy to recover from the effects of global financial crisis, curtails inflation, and provided stability of economic performance. Inflation rates remained low and within acceptable levels in year 2011 maintaining $0.88 \%$ from year 2010, based on index of consumer prices. Stable index of consumer prices is attributed to the fall in real property rentals by $2.4 \%$ in year 2011 and the decrease in clothing and footwear prices by $1.09 \%$.

UAE Inflation rate is expected to be $4.2 \%$ by the end of 2015. In the long-term, it is projected to trend around $5.24 \%$ in year 2020, 5.24\% in year 2030 and $5.24 \%$ in year 2050, according to our econometric models.

Emerging Markets Monitor [9], reports that inflation rates in UAE was expected to decrease since the start of 2009 as a result of the declining housing costs and the moderate level of food price inflation. The rates of inflation in UAE are higher from year 2002 to 2008 due to its natural gases and oil reserves, Market: Africa/Middle East [16]. Upward pressure on inflation rate in the UAE is due to education costs, food, and alcoholic beverages, Martin [17], while inflationary pressures fell in the context of the 2008 global financial crisis, United Arab Emirates Monitor [33].

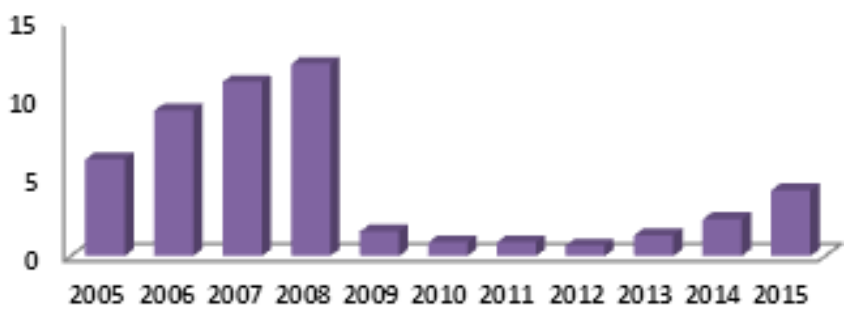

Figure 4. UAE Inflation Rates (Year: 2005 - 2015)

\subsubsection{Population Growth}

Estimates of population growth in UAE are based on the average annual percent change, resulting from a surplus or deficit of births over deaths and the balance of migrants entering and leaving the country. A positive growth rate determines the challenge imposed on the country by the changing needs of its people for infrastructure and jobs. The total population of UAE till mid 2010 estimated by around 8.26 million persons, recording a growth rate of $4 \%$ in year 2007 , gradually lowered $3.83 \%$ in year $2008,3.69 \%$ in 2009 , and lower rates in subsequent years up to 2014 . The growth rate is expected to rise to $9.7 \%$ in 2016 . The economy is experiencing growth in economic performance and expected to maintain stability in the coming years with the government efforts to achieve long-term development objectives for year 2021. The country is projected to witness population growth as the nation becomes a preferred destination for living, promising job opportunities, and local and foreign investments.

\section{POPULATION GROWTH}

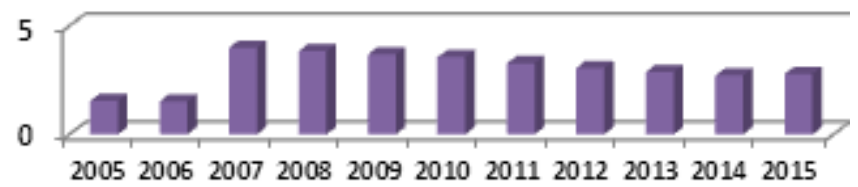

Figure 5. UAE Population Growth (2005-2015)

\subsection{Economic Sustainability of United Arab Emirates}

United Arab Emirates has a commodity-based economy with oil shipments and natural gas contributing to $40 \%$ of total exports, equivalent to $38 \%$ of Gross Domestic Product, Annual Economic Report [2]. It has one of the world's highest GDP per capita, providing huge investments in financial, construction, and tourism sectors as a strategy for economic diversification and reduction of dependence on oil revenues. In 2012, drivers of economic growth included tourism, which accounted for $15.5 \%$ of output growth, manufacturing activities, wholesale and retail trade, and transport and communication sectors. Economic stability was gradually achieved with the process of diversification 
and the recovery witnessed by the real estate and construction industry. The country is seen to enjoy a strong economy supported by effective economic and investment policies and ideal investment climate creating a strong positive impact on the flow of foreign investments.

As in Figure 6, Gross Domestic Product growth rate in UAE was $4.6 \%$ in 2014 and averaged $4.82 \%$ from 2000 to 2014 , reaching a high record of $9.80 \%$ in 2006 and a low record of $-5.20 \%$ in 2009, Trading Economics [30]. Real gross domestic product of UAE in 2012 reached AED 1025.6 billion compared to AED 982.7 billion in 2011, fostering the development of non-oil sectors that grew by $3.4 \%$ representing $67.3 \%$ of UAE's GDP. GDP Growth Rate is projected at $4.6 \%$ by the end of 2015 and to trend around $4.28 \%$ in $2020,4.24 \%$ in 2030 and $4.24 \%$ in 2050 . UAE managed to overcome the effects of global financial crisis, financial difficulties of European nations, and the rise in unemployment rate, through its balanced economic policies. and effective government leadership (delete this sentence green highlighted). Despite the global economic crisis, UAE economy enjoyed the benefits of economic diversification, increased spending in infrastructure projects, rise in oil prices, and tourism projects. UAE continues to attract more foreign investments through the creation of a favorable investment climate and laws that promote economic climate and business environment.

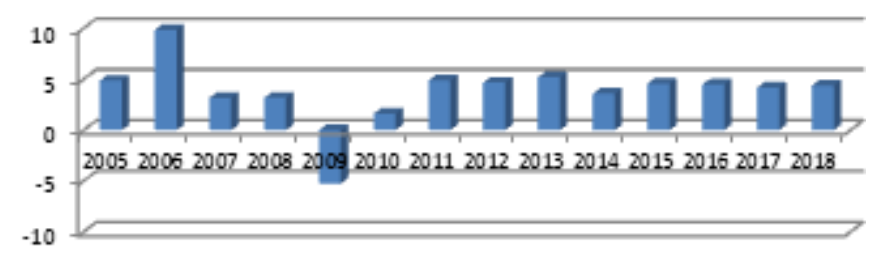

Figure 6. GDP Rate of Growth, Year: 2005 - 2018

As presented in Figure 6, the UAE economy achieved a rising growth rate of $4.89 \%$ in 2013 to a high record of $5.2 \%$ in 2013. The driving force for sustainable performance in the non-oil sector is attributed to immense financial surpluses in infrastructure projects. Stability remains the hallmark of the nation economic activity with a continuing focus on infrastructure projects expenditures. It is expected that stability of the various industries, improvements in the real estate industry, tourism, and rising growth in economic performance will contribute to the nation attractiveness for investments. The generated growth rates of UAE demonstrate the success of the diversification policy on income sources and reduction of oil reliance in the light of global financial crisis. The high level of oil prices boosted government revenues and provided resources for public spending and stimulation of investment.

\subsection{Significant Influence of the Macroeconomic Indicators in UAE on Sustainability of Economic Performance}

\section{A. Increased Unemployment Rates in UAE Lead to Decreased Economic Performance Sustainability}

As presented in Table 1, Pearson product-moment correlation coefficient measures the strength and direction of association that exists between pairs of continuous variables of economic indicators and economic performance sustainability in an interval scale. Also, it evaluates statistical evidence of linear relationships among the pairs of variables. The $\rho$ value of 0.759 of unemployment variable, for two-tailed test of significance, reveals no significant influence of unemployment on economic performance sustainability, at both $5 \%$ and $10 \%$ significance levels. The null hypothesis is accepted and the two variables are not significantly correlated. This finding implies that, for the last ten years, UAE experienced economic growth and was not influenced by variations in unemployment levels therein. The magnitude of Pearson Correlation value of -0.105 less than the tabular value of 0.3 indicates weak negative correlation between unemployment rates and economic performance sustainability proving that increases in unemployment rates will lead to decreases in economic performance sustainability.

Moreover, to further substantiate the above finding, the scatter plot in Figure 7, which determines the directional relationship between unemployment and economic performance sustainability, shows scatter clouds that adhere marginally to the trend line indicating negative correlation between the two variables. The Figure shows the scatter plot of unemployment rates and economic performance sustainability.

The above finding is supported by the research of Patton [21] that presented the evidence of the inverse relationship between unemployment and economic performance. Economic recovery is expected to falter, unless unemployment rate goes down to a reasonable level. As unemployment rises, most of the time GDP falls and vice versa. The negative correlation between unemployment and GDP indicates that the two variables move in opposite direction, thus there is a significant negative relationship between the two indicators.

Table 1. Significant Influence of Economic Indicators on Sustainability of Economic Performance

\begin{tabular}{|c|c|c|c|c|c|c|c|}
\hline Indicators & $\mathrm{N}$ & Std. Deviation & Mean & Pearson Correlation & Sig.(2-tailed) & Sum of Squares & Covariance \\
\hline Unemployment & 11 & 0.566 & 3.84 & -0.105 & 0.759 & -2.137 & -0.214 \\
\hline Inflation & 11 & 4.41 & 4.62 & 0.283 & 0.399 & 44.9 & 4.49 \\
\hline Population Growth & 11 & 0.838 & 2.99 & -0.631 & $0.037^{*}$ & -19 & -1.9 \\
\hline
\end{tabular}

** Correlation is significant at the .01 level (2-tailed).

*Correlation is significant at the .05 level (2-tailed). 
The above finding is also in line with that of Rahman [22], where he concluded that gross domestic product and per capita GDP are basic measures of a country's economic performance, but GDP is not significantly related with literacy rate or unemployment rate. There is a significant negative relationship both between per capita GDP and unemployment rate and between literacy and unemployment rate and therefore per capita GDP plays a significant role in changing literacy rate and unemployment rate. To reduce unemployment rate, proper initiatives must be taken to increase literacy thereby increasing GDP which can result in the development of a country.

\section{UNEMPLOYMENT RATES}

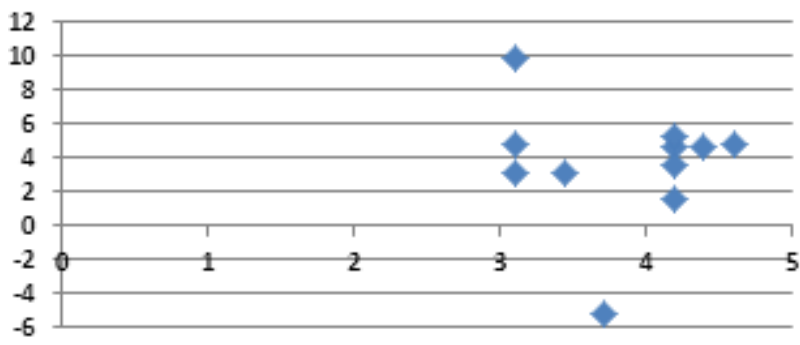

Figure 7. Scatter Plot of Unemployment (X axis) and GDP Growth Rate (Y axis)

\section{B. Low Inflation Rates in UAE Increase Economic Performance Sustainability}

As presented in Table 1, the $\rho$ value for two-tailed test of significance of 0.399 for inflation rates and economic performance sustainability, show no significant influence at both $5 \%$ and $10 \%$ significance level. The null hypothesis is accepted, and the two variables are not significantly correlated. This finding implies that, for the last ten years, UAE experienced economic growth and was not influenced by variations in inflation rates thereon. The magnitude of Pearson Correlation value of 0.283 indicates weak positive correlation between inflation rates and economic performance sustainability which suggests that changes in inflation rates are not correlated with changes in the growth rate in GDP. The weak positive correlation between the two variables indicates that increases in inflation rates led to slight increases in economic performance sustainability in $\mathrm{UAE}$, in the last ten years.

Moreover, to further prove the above finding, the scatter plot in Figure 8, which determines direction of the relationship between inflation rates and economic performance sustainability, shows scatter clouds that adhere marginally to the trend line indicating weak positive correlation between the two variables. Figure 8 shows the scatter plot of inflation rates and economic performance sustainability.

The finding indicates positive and rising economic performance in UAE as inflation rate remained low and within acceptable levels in 2011, maintaining the percentage of 0.88 since 2010 , caused by contraction of aggregated demand and government measures to reduce high prices. Fall in the real property rentals by $2.4 \%$ in 2011 and decrease in prices of clothing and footwear by $1.09 \%$ are other important reasons for the stable inflation rates in the country contributing to an increased level of economic performance.

This finding is line with those of Stockman [27] and Istaitieh [14]. Countries which experience higher than average inflation in general have slower than average output growth. When initial levels of inflation are low, inflation does not necessarily hurt an economy. High initial levels of inflation retard economic growth, with the average person becoming less well-off. UAE has been experiencing creeping inflation for the past five years, with $6.2 \%$ in 2005 . There is an evident need for the UAE authorities to take measures for preventing further increases in inflation levels which can hinder future economic growth.

\section{INFLATION RATES}

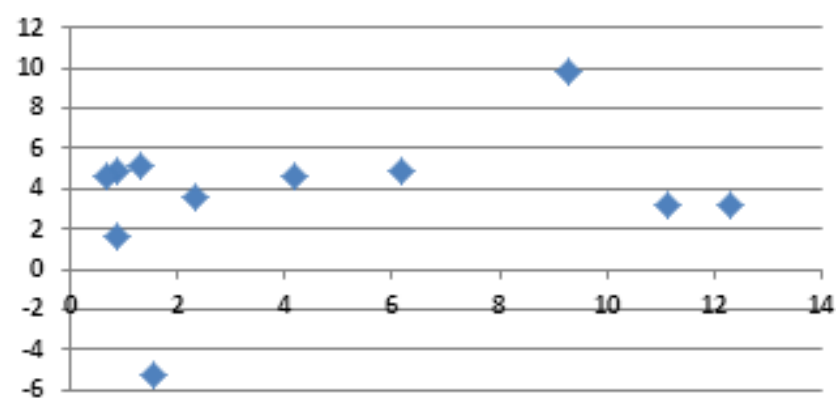

Figure 8. Scatter Plot for Inflation Rates (X axis) and Economic Performance Sustainability(Y axis)

\section{Increased Population Growth Rates in UAE Lead to Decreased Economic Performance Sustainability}

As shown in Table 1, population growth and economic performance sustainability reveal $\rho$ value of $.037^{*}$, significant. There is a significant relationship between population growth and economic performance sustainability at $5 \%$ level of significance. The null hypothesis is rejected and the two variables are significantly correlated. A change in the level of population growth will lead to changes in the level of economic performance sustainability. The correlation coefficient of -0.631 for population growth and output growth reveals a high negative correlation which implies that the increases in population growth over the last ten years in the country, will lead to a decrease in economic performance sustainability in the long-run. To further prove this finding, the scatter plot of population growth and economic performance sustainability in Figure 9 shows strong negative correlation. With all points falling directly on a downward inclined line, presenting a negative correlation between the two variables. This finding implies that increases in population growth are correlated with decreases in economic performance sustainability. Findings show UAE population growth gradually lowering from 2007 to 2015 which resulted in increased economic growth of the country maintaining stability in economic performance until the current year. Projections reveal that population will grow in the next future period as the country becomes a preferred destination for living, promising job opportunities, and local and foreign investments. 


\section{POPULATION GROWTH}

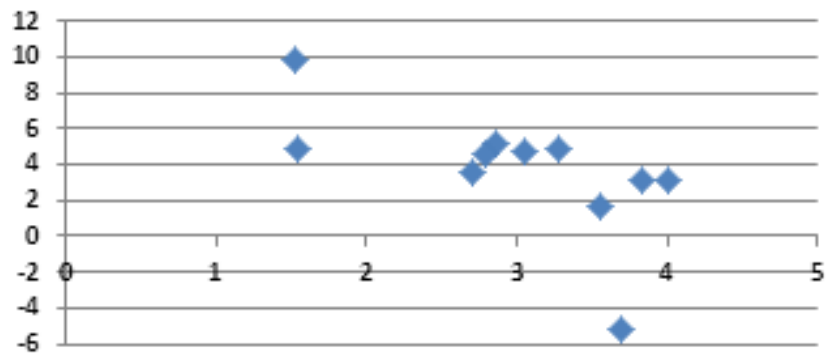

Figure 9. Scatter Plot of Population Growth (X axis) and Economic Performance Sustainability (Y axis)

Elhiraika and Hamed [8] explained the determinants of aggregate GDP growth in UAE as oil-dependent country and confirm the predominance of labor in total GDP growth, with a negative contribution by total factor productivity growth to overall GDP growth. This was due to negative biases caused by fluctuations of oil prices, insufficient skilled labor to complement capital, and the nature of investments.

In general, the UAE macroeconomic indicators signal a healthy, booming economy experiencing steady growth.

\subsection{Significant Difference in Economic Performance of UAE in the Past Ten years and in the Long-Term}

Table 2. Independent Samples Test for Significant Difference in the Level of Economic Performance over the Past Ten years and in the Long-Term

\begin{tabular}{|c|c|c|c|c|c|}
\hline & GRP & N & Mean & $\begin{array}{c}\text { Std. } \\
\text { Deviation }\end{array}$ & $\begin{array}{c}\text { Std. Error } \\
\text { Mean }\end{array}$ \\
\hline \multirow{2}{*}{ EP } & $\mathbf{1 . 0 0}$ & 11 & 3.6764 & 3.59421 & 1.08369 \\
\cline { 2 - 6 } & $\mathbf{2 . 0 0}$ & 11 & 4.3364 & .07366 & .02221 \\
\hline
\end{tabular}

Levene's test for equality of variances tests the null hypothesis that economic performance over the past ten years and economic growth in the long-term have equal variances. Test statistic of 0.019 indicates that the two time periods have unequal variances (with equal variances assumed), and the null hypothesis is false. This indicates the use of statistic associated with equal variances not assumed for the t-test for Equality of Means.

The T-test result, with equal variances not assumed, shows t-statistic of 0.609 with 10.0 degrees of freedom. The corresponding two-tailed $\rho$ value is 0.556 , is higher at both $1 \%$ and $5 \%$ level of significance. The null hypothesis is accepted at both significance levels which means that values of economic performance of UAE in these time periods are just the same. This finding implies that the rising trend of economic performance of UAE in the past ten years will continue over the long-term.

\subsection{Macroeconomic Indicators Significantly Predict Economic Performance of UAE}

Table 4 presents the regression coefficients and their significance. The regression coefficients were used to construct an "Ordinary Least Squares" equation and an equation for predicting economic performance was constructed. As shown in the table, unemployment rates, inflation rates, and population growth rates, indicated by the $\rho$ value of $0.043,0.032$, and 0.008 , respectively, significant at $5 \%$ level of significance, are predictors of economic performance sustainability and are related to economic performance sustainability at $5 \%$ level of significance.

Table 3. Independent Samples Test

\begin{tabular}{|c|c|c|c|c|c|c|c|c|c|c|}
\hline & & \multirow{2}{*}{\multicolumn{2}{|c|}{$\begin{array}{l}\text { Levene's Test } \\
\text { for Equality of } \\
\text { Variances }\end{array}$}} & \multicolumn{7}{|c|}{ t-test for Equality of Means } \\
\hline & & & & & & & & & $\begin{array}{r}95 \% \text { Co } \\
\text { Interva } \\
\text { Diffe }\end{array}$ & $\begin{array}{l}\text { dence } \\
\text { f the } \\
\text { ice }\end{array}$ \\
\hline & & $\mathrm{F}$ & Sig. & $\mathrm{t}$ & $\mathrm{df}$ & $\begin{array}{c}\text { Sig. } \\
\text { (2-tailed) }\end{array}$ & $\begin{array}{c}\text { Mean } \\
\text { Difference }\end{array}$ & $\begin{array}{l}\text { Std. Error } \\
\text { Difference }\end{array}$ & Lower & Upper \\
\hline $\begin{array}{l}E C O N \\
O M I C\end{array}$ & $\begin{array}{c}\text { Equal } \\
\text { variances } \\
\text { assumed } \\
\end{array}$ & 6.557 & .019 & -.609 & 20 & .549 & -.66000 & 1.08392 & -2.92102 & 1.60102 \\
\hline $\begin{array}{c}\text { PERFOR } \\
\text { MANCE }\end{array}$ & $\begin{array}{c}\text { Equal } \\
\text { variances } \\
\text { not assumed }\end{array}$ & & & -.609 & 10.008 & .556 & -.66000 & 1.08392 & -3.07485 & 1.75485 \\
\hline
\end{tabular}

Table 4. Regression Model Summary

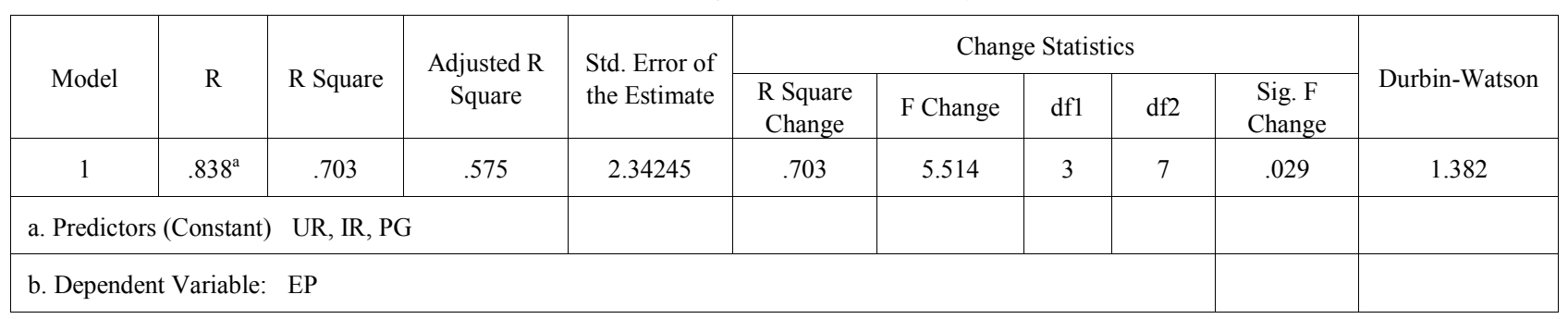


The table shows $70.3 \%$ can be explained by the independent variables of unemployment, inflation, and population growth rates. It indicates that $\mathrm{R}$ values for assessing the overall fit of the regression model. The $\mathrm{R}$ Square value shows the proportion of variance in the variable of economic performance which can be explained by the three economic indicators, indicating the overall measure of the strength of association. The coefficient of determination or R-Square value of 0.703 indicates $70.3 \%$ or the proportion of the total variation in economic performance variable explained by the regression model. The Adjusted $\mathrm{R}$ value is 0.575 , which indicates that the three independent variables unemployment, inflation, and population growth rates account for $57.5 \%$ of variance in economic performance sustainability.

Table 5. Analysis of Variance

\begin{tabular}{|c|c|c|c|c|c|c|}
\hline \multicolumn{2}{|c|}{ Model } & $\begin{array}{c}\text { Sum of } \\
\text { Squares }\end{array}$ & df & $\begin{array}{c}\text { Mean } \\
\text { Square }\end{array}$ & F & Sig. \\
\hline \multirow{2}{*}{1} & Regression & 90.774 & 3 & 30.258 & 5.514 & $.029^{\mathrm{a}}$ \\
\cline { 2 - 7 } & Residual & 38.409 & 7 & 5.487 & & \\
\cline { 2 - 7 } & Total & 129.183 & 10 & & & \\
\hline
\end{tabular}

a. Predictors (Constant) UR, IR, PG

b. Dependent Variable: EP

The ANOVA table shows how well the regression equation fits the data and predicts economic performance variable. The p-value of 0.029 is less than .05 and .1 , indicating statistical significance of the regression model that was run. This finding reveals that the regression model is a good fit for the data, and statistically significantly predicts the outcome variable of economic performance sustainability.

\subsection{Ordinary Least Square's Equation for Economic Performance Sustainability in UAE}

The model in Table 6 shows that $8.57 \%$ of unemployment rates, $3.28 \%$ of inflation rates, and $-8.31 \%$ of population growth rates can result in economic sustainability over the long-run and still maintain competitiveness in the global economic environment. Regression coefficient variancedecomposition matrix shows the proportion of variance for each regression coefficient attributable to each condition index. The p-value for beta coefficient of unemployment rates is .043 , p-value for beta coefficient of inflation rates is .032 , and .008 for population growth, significant at both $5 \%$ and $10 \%$ significance levels, the null hypotheses for the three variables are rejected. Economic performance sustainability is positively related to economic indicators variables of unemployment rates, inflation rates, and population growth rates and are predictors of economic performance sustainability.

Table 6 shows collinearity statistics with values of tolerance and variance inflation factor that measures the impact of collinearity among the variables in the regression model. Low Variance Inflation Factors of 3.185 for unemployment rates, 2.982 for inflation rates, and 1.182 for population growth rates, less than 5 , indicate the absence of multicollinearity among the economic indicators variables. The table also presents Tolerance values that describe the variability of the economic indicators variables not explained by other predictor variables. Economic indicators of unemployment rates, inflation rates, and population growth rates have tolerance values of $0.314,0.335$, and 0.846 , respectively, greater than 0.2 , indicating the absence of multicollinearity in the model. The variables of unemployment rates, inflation rates, and population growth rates are linearly independent indicating no perfect linear relationship among the independent variables.

Table 6. Regression Coefficients

\begin{tabular}{|c|c|c|c|c|c|c|c|c|c|c|}
\hline & \multirow[t]{2}{*}{ Model } & \multicolumn{2}{|c|}{$\begin{array}{l}\text { Unstandardized Co- } \\
\text { efficients }\end{array}$} & \multirow{2}{*}{$\begin{array}{c}\begin{array}{c}\text { Standardized } \\
\text { Co-efficients }\end{array} \\
\text { Beta }\end{array}$} & \multirow[t]{2}{*}{$\mathrm{t}$} & \multirow[t]{2}{*}{ Sig. } & \multicolumn{2}{|c|}{$\begin{array}{c}95 \% \\
\text { Confidence } \\
\text { Interval for B }\end{array}$} & \multicolumn{2}{|c|}{$\begin{array}{l}\text { Collinearity } \\
\text { Statistics }\end{array}$} \\
\hline & & B & $\begin{array}{l}\text { Std. } \\
\text { Error }\end{array}$ & & & & Lower Bound & $\begin{array}{l}\text { Upper } \\
\text { Bound }\end{array}$ & Tolerance & VIF \\
\hline \multirow{4}{*}{1} & (Constant) & 10.140 & 9.381 & & -1.081 & .316 & -32.322 & 12.041 & & \\
\hline & $\begin{array}{c}\text { Unemployment } \\
\text { Rate }\end{array}$ & 5.438 & 2.335 & 0.857 & 2.329 & 0.043 & -0.082 & 10.958 & 0.314 & 3.185 \\
\hline & Inflation Rate & 0.372 & 0.290 & 0.328 & 2.663 & 0.032 & 0.086 & 1.457 & 0.335 & 2.982 \\
\hline & $\begin{array}{c}\text { Population } \\
\text { Growth Rate }\end{array}$ & -3.564 & 0.961 & -0.831 & -3.709 & 0.008 & -5.836 & -1.291 & 0.846 & 1.182 \\
\hline
\end{tabular}

Table 7. Collinearity Diagnostics

\begin{tabular}{|c|c|c|c|c|c|c|c|}
\hline \multirow{2}{*}{ MModel } & \multirow{2}{*}{ Dimension } & \multirow{2}{*}{ IEigen Value } & \multirow{2}{*}{$\begin{array}{l}\text { cCondition } \\
\text { Index }\end{array}$} & \multicolumn{4}{|c|}{ Variance Proportions } \\
\hline & & & & (Constant & Unemployment Rate & Inflation Rate & Population Growth \\
\hline \multirow{4}{*}{1} & 1 & 3.533 & 1.000 & .00 & .00 & .01 & .00 \\
\hline & 2 & .423 & 2.891 & .00 & .00 & .29 & .01 \\
\hline & 3 & .642 & 9.192 & .03 & .02 & .00 & .82 \\
\hline & 4 & .803 & 10.586 & .97 & .88 & .70 & .07 \\
\hline
\end{tabular}


Table 7 shows condition index values for the measure of multicollinearity in the regression model. Variance Proportions values of economic indicators, less than 0.9 corresponding to Condition Index values in excess of 30 , indicate the absence of multicollinearity in the data. Condition Index values shown in the table, less than 15 indicates no collinearity among the variables. Eigen values in the table provide an indication of the distinct dimensions of economic indicators variables. Eigen values of 3.53, 0.423, 0.642 , and 0803 far from zero, the variables are not intercorrelated which may lead to large changes in the estimates of the regression coefficients.

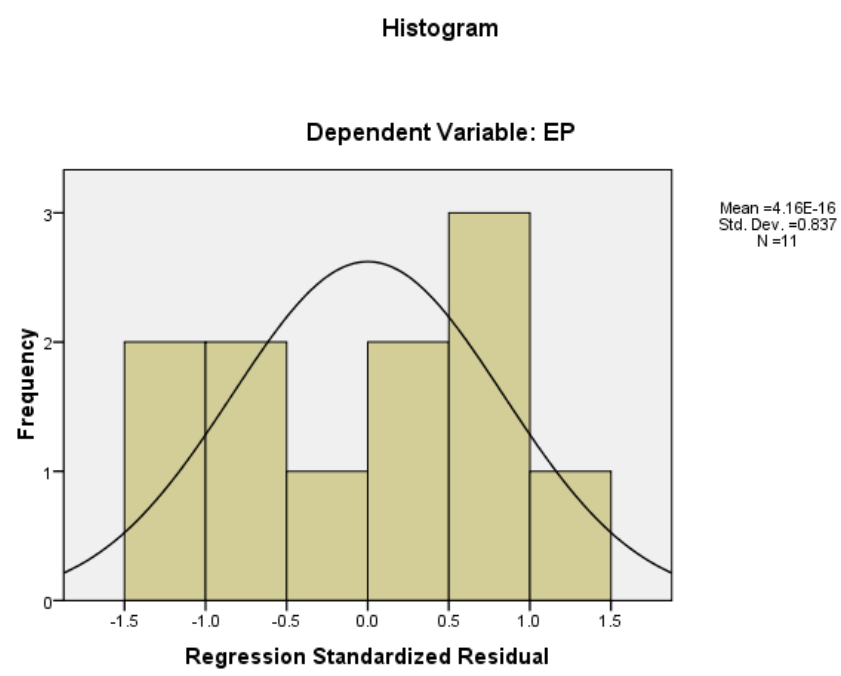

Figure 10. Regression Standardized Residual

Analysis of residuals was used as a diagnostic tool to assess whether the regression analysis has explained as much variation in the dependent variable of economic performance and determine violations of the underlying assumptions of regression. Figure 10 presents a histogram of the residuals with a normal curve superimposed and residuals appear close to normal. It shows the residual or vertical distance between economic performance data points and the regression line, indicating the error, not explained by the regression line. The plot of the residuals versus predicted economic performance shows a pattern of the absence of problems with the assumption that the residuals are normally distributed at each level of $Y$ and the constant in variance across levels of $Y$. All residuals are small and unstructured which imply that the regression analysis has been successful in explaining the essential part of the variation of the dependent variable of economic performance.

\section{Normal P-P Plot of Regression Standardized Residual}

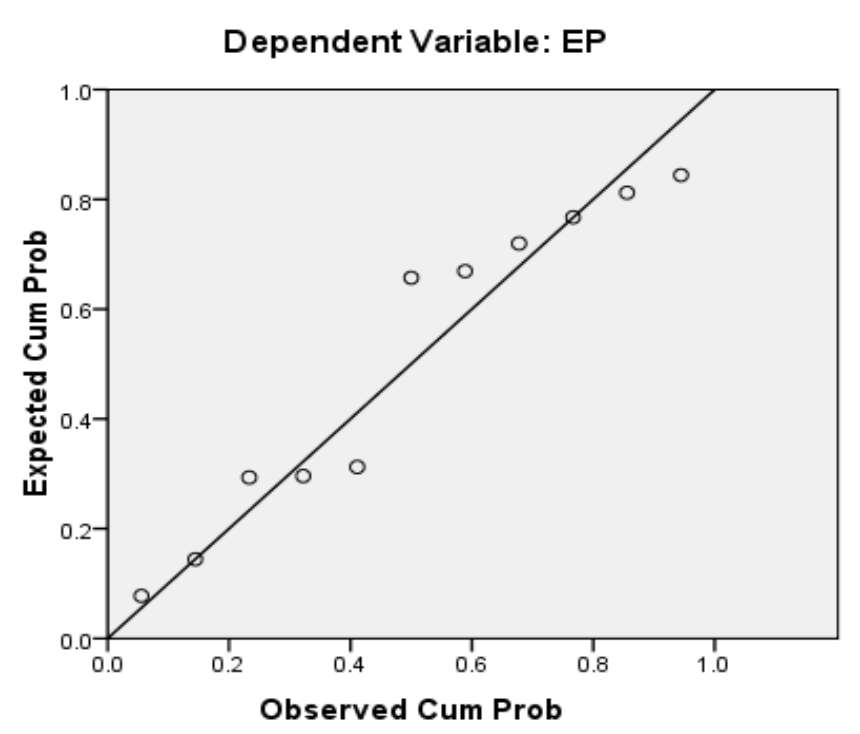

Figure 11. Normal P-P Plot of Regression Standardized Residual

To determine satisfaction of the assumption for normality of residual distribution, the normal P-P plot of the regression standardized residual was examined. The criterion for normal distribution is the degree to which the plot for the actual values coincides with the line of expected values. The plot of residuals was examined and obtained to verify the normality assumption and assess any violation of the assumption. The data appears as collection of points, clustering, and randomly scattered around the straight line with constant variability along the line. The plot of residuals fits the expected pattern and is sufficient to support the conclusion that the residuals are normally distributed.

\subsection{Chi-Square Test to Test Independence of Categorical Economic Indicators Variables and Sustainability of Economic Performance in UAE}

Table 8. Case Processing Summary

\begin{tabular}{|c|c|c|c|c|c|c|}
\hline & \multicolumn{6}{|c|}{ Cases } \\
\hline & \multicolumn{2}{|c|}{ Valid } & \multicolumn{2}{c|}{ Missing } & \multicolumn{2}{c|}{ Total } \\
\cline { 2 - 7 } & $\mathrm{N}$ & Percent & $\mathrm{N}$ & Percent & $\mathrm{N}$ & Percent \\
\hline $\begin{array}{c}\text { Economic } \\
\text { Indicators* } \\
\text { Economic } \\
\text { Performance }\end{array}$ & 11 & $100.0 \%$ & 0 & $.0 \%$ & 11 & $100.0 \%$ \\
\hline
\end{tabular}


Table 8 presents the Case Processing Summary showing details about the cases in the data file. The table reveals suitability of the Chi-Square Test, with all the cases in the cells greater than 0.09 .

Table 9. Chi-Square Tests

\begin{tabular}{|c|c|c|c|}
\hline & Value & df & $\begin{array}{c}\text { Asymp. Sig. } \\
\text { (2-sided) }\end{array}$ \\
\hline Pearson Chi-Square & 110.000 & 100 & .232 \\
\hline Likelihood Ratio & 52.754 & 100 & 1.000 \\
\hline $\begin{array}{c}\text { Linear-by-Linear } \\
\text { Association }\end{array}$ & 1.299 & 1 & .254 \\
\hline N of Valid Cases & 11.000 & & \\
\hline
\end{tabular}

\section{Minimum expected count is 0.09}

The Chi-square test of independence is used to test the hypothesis that the economic indicators and the sustainability of economic performance of UAE are independent of each other. Two-sided significance presented in Table 9 shows Pearson Chi-Square value of 110.0 and $\rho$ value equivalent to .232 greater than significance levels at both $5 \%$ and $10 \%$. The null hypothesis is accepted. Economic indicators and sustainability of economic performance of UAE are not independent of each other.

Findings imply that changes in the rates of unemployment, inflation, and population growth will cause a change in the sustainability of economic performance in UAE. The current trends of economic indicators in the country contribute to increasing level of economic performance in the long-run.

\section{Conclusions}

Stability remains the hallmark of the UAE economic activity with a continuing focus on infrastructure projects expenditures as growth in the various industries, improvements in the real estate industry, tourism, and rising growth in economic performance will allow UAE to achieve sustainability in economic performance. The economy is experiencing growth in economic performance and expected to maintain stability in the coming years with the government efforts to achieve long-term development objectives for year 2021 .

The independent variable of unemployment rates reveals no significant influence on economic performance sustainability, at both $5 \%$ and $10 \%$ significance levels. The null hypothesis is accepted which implies that, in the last ten years, the country experienced economic growth and was not influenced by variations in unemployment levels. However, increases in unemployment rates will lead into decreases in economic performance sustainability in the long-run, and vice-versa. The independent variable of inflation rates shows no significant influence on economic performance at both $5 \%$ and $10 \%$ significance level. The null hypothesis is accepted, and this finding implies that, for the last ten years, the country experienced economic growth and was not influenced by variations in inflation rates in the country.
The decline in inflation rates in the UAE economy fosters financial stability. Such rates remained low and within acceptable levels in the previous years and will continue to maintain stability in the long-run.

However, there is a significant relationship between the independent variable of population growth rates and economic performance sustainability at 5\% level of significance. The null hypothesis is rejected, a change in the level of population growth will lead to changes in the level of economic performance sustainability. The correlation coefficient of -0.631 reveals high negative correlation which implies that increases in population growth over the last ten years in the country, will lead to a decrease in economic performance sustainability in the long-run. The positive growth rate determines the challenge imposed in the country by the changing needs of its people for infrastructure and jobs. The country is projected to witness population growth as the nation becomes a preferred destination for living, promising job opportunities, and local and foreign investments.

The T-test analysis for significant difference of UAE economic performance in the last ten years and over the long-run result in acceptance of the null hypothesis: the two time periods are just the same. The rising trend of economic performance of UAE in the past ten years will continue over the long-run. The three economic indicators - unemployment, inflation, and population growth rates - are positively related and strong predictors of economic performance sustainability. Chi-Square Test of Independence results in acceptance of null hypothesis. Economic indicators and sustainability of economic performance of UAE are not independent of each other which implies that changes in the growth rates of the three economic indicators will cause a change in the sustainability of economic performance in UAE. The current trends of economic indicators in the country contribute to the increasing level of economic performance for sustainability in the long-run and are projected to continue in the next future.

\section{Recommendations}

1. Conduct further studies that focus on variables not included in the study that are likely to influence the level of UAE economic performance.

2. Monitor the level of population growth which is significantly correlated with economic performance.

3. Develop other economic policies that will determine an increase in the nation economic performance and achieve sustainability in the long-run.

4. Formulate economic policies and strategies to overcome significant long-term challenges on oil dependence, growing expatriate workforce, and inflationary pressures.

5. Develop strategic plans to continuously reduce the current unemployment and inflation rates in the country. 
6. Monitor effective implementation of government plans and policies designed to achieve economic growth and sustainability in the long term.

\section{REFERENCES}

[1] Al-Habees, M., \& Rumman, A. The Relationship between Unemployment and Economic Growth in Jordan and Some Arab Countries. World Applied Sciences Journal, (2012), 18 (5): 673-680. IDOSI Publications. Jordan. ISSN: 1818-4952.

[2] Annual Economic Report. Global, Arab, and Gulf Economic Developments. $21^{\text {st }}$ Issue, Ministry of Economy, (2013), United Arab Emirates.

[3] Barlow, R. Population Growth and Economic Growth: Some More Correlations. Population and Development Review, (1994), 20(1), 153-165. Available from: http://www.jstor.org /stable/2137634.

[4] Bchir, M. H., \& Rajhi, T. Short Term Economic Responses to Unemployment in Arab Region. (2012), Available from: file://F:/MACROECO\%20EXTENDED\%20VERSION/Sho rt_term_economic_responses_to_unemployment_in_Arab_ Rèio_-̄12_11_20121.pdf.

[5] Bean, C., \& Pissarides, Ch. Unemployment, Consumption, and Growth. European Economic Review, (1993), 37(4), 837-854. Available from: http://www.sciencedirect.com/scie nce/article/pii/001429219390093P.

[6] Country Report. Risks to UAE Growth. Middle East Monito: The Gulf. (2006), 6(9), 6, UAE. ISSN: 1469-5251, Available from: http://web.b.ebscohost.com/ehost/detail/detail?sid.

[7] Econs. Vicious Circle of Growth, Economics Tuition Singapore, (2015), WordPress. Available from: http://www.econs.com.sg/free-downloads/economic-growth/

[8] Elhiraika, A., \& Hamed, A. Explaining Growth in an Oil-Dependent Economy: The Case of United Arab Emirates, (2002), The College of Information Sciences and Technology. Pennsylvania State University. CiteSeerX. Available from: http://citeseerx.ist.psu.edu/viewdoc/summar $\mathrm{y}$ ?doi=10.1.1.199.702.

[9] Emerging Markets Monitor. UAE: Inflation Data Boost to Transparency, (2009), Article. 15(10), 19. UAE Colliers International Incorporated. ISSN: 1359-0006.

[10] Everington, J. UAE Urban Population Will Grow to 7.9 Million by 2020, (2013), The National Business. Available from: http://www.thenational.ae/business/industry-insights.

[11] Furuoka, F. Population Growth and Economic Development: Empirical Evidence from the Philippines. Philippine Journal of Development, (2010), 37(1), 81-93, Philippine Institute for Development Studies. ISSN: 0115-9143. Available from:http://web.a.ebscohost.com/ehost/detail/detail?

[12] IECONOMICS. United Arab Emirates Unemployment Rate 2015, (2015), Available from: http://ieconomics.com/unitedarab-emirates-unemployment-rate-forecast.

[13] Ibrahim, A, \& Hellyer, P. United Arab Emirates: A New Perspective, (2001), Trade Press Ltd., pp. 251-252, United Kingdom, ISBN: 1-900724-04-9, Available from: www.tridentpress.com.

[14] Istaitieh, A., Hugo, S., \& Husain, N. Inflation. Macroeconomic Report Series, (2007), P.7. DCCI: Data Management and Business Research Department. Chamber of Commerce and Industry, Dubai, UAE, Available from: www.dcci.ae.

[15] Manchin, S., \& Manning, A. The Causes and Consequences of Long-term Unemployment in Europe. Handbook of Labor Economics, (2005), Chapter 47, Vol. 47, Part C., 3085-3139. ScienceDirect, Elsevier. DOI: 10.1016/S1573-4463 (99)30035-9. Available from: http://www.sciencedirect.com/ science/article/pii/S1573446399300389.

[16] Market: Africa / Mid-East. Inflation Could Pose Problem for the UAE, (2008), Article. 13(1), 8. ISSN: 1083-5512.

[17] Martin, M. UAE Inflation Shows Little Growth. Middle East Economic Digest, (2011), 55(43), 20. United Arab Emirates. ISSN: 0047-7238.

[18] Ossman, G. Rights and Duties of Transnational Corporations under Economic Law, Journal of International Company and Commercial Law Review, (1996), 7(4), 139-148. Sweet and Maxwell, UK. ISSN: 0958-5214.

[19] Ossman, G. Recent Developments in Institutional and Managerial Aspects of Business Administration in Japan, Journal of International Company and Commercial Law Review, (1998), 9(2), 57-62. Sweet and Maxwell, UK. ISSN: 0958-5214.

[20] Ossman, G. "Macroeconomics of Labor Markets in the Kingdom of Bahrain: Effects on Planned Aggregate Expenditures". 2nd ICMRP Book of conference Proceedings, (2014), p.13. $2^{\text {nd }}$ International Conferences on Innovation Challenges in Multidisciplinary Research \& Practice. Global Illuminators Publishing, Kuala Lumpur, Malaysia. ISBN: 978-969-9948-08-4. Available from: http://www.globalillum inators.org.

[21] Patton, M. The Key to Economic Growth: Reduce The Unemployment Rate. Forbes Article, (2012), Available from: http://www. Forbes.com/sites/mikepatton/2012/08/27.

[22] Rahman, S. M. Relationship among GDP, Per Capita GDP, Literacy Rate, and Unemployment Rate. Proceedings: $11^{\text {th }}$ Islamic Countries Conference on Statistical Sciences, (2011), 21, pp. 103-111. Islamic Countries Society of Statistical Sciences. ISOSS, Pakistan. ISBN: 978-969-8858-09-4. Available from: http://www.isoss.net.

[23] Sherif, S. Macroeconomic Policy, Localization, and Reducing Unemployment: The Human Resource Issues for the UAE Competitiveness Review. International Business Journal, (2013), 23(2), 158-174. Emerald Group Publishing Ltd. ISSN: 1059-5422. Available from: http://www.emeraldinsight.com/ doi/abs/10.1108/10595421311305352.

[24] Simon, J., \& Gobin, R. The Relationship between Population and Economic Growth in LDC's. Research Population Economics, (1980), 2, 215-234, Document No: 800684, JAI Press, Greenwich, Connecticut, POPLINE, Available from: http://www.popline.org/node/447702.

[25] Simpson, S. Macroeconomics: Inflation. Investopedia, LLC, (2015), Available from:http://www.investopedia.com/univer sity/macroeconomics/macroeconomics6.asp.

[26] Solow, R. M. Contribution to the Theory of Economic Growth. Quarterly Journal of Economics, (1956), 70(1), 65-95, JSTOR, Oxford University Press. Available from: 
http://www.jstor.org/stable/1884513.

[27] Stockman, A. C. Anticipated Inflation and the Capital Sock in a Cash-in-Advance Economy. Journal of Monetary Economies, (1981), 8(3), 387-393.

[28] Trading Economics. United Arab Emirates Unemployment Rate: 1985-2016. (2016). United Arab Emirates.

[29] Trading Economics. United Arab Emirates Inflation Rate: 1990-2016. (2016). United Arab Emirates.

[30] Trading Economics. United Arab Gross Domestic Product. (2016). United Arab Emirates.

[31] United Arab Emirates, Ministry of Economy. Inflation. Annual Economic Report, (2012), Issue: 20, p. 23. National Economic Development Board. Planning and Decision
Support Department, UAE. Available from: http://www.economy.ae.

[32] United Arab Emirates, Ministry of Economy. Population and Labor Force. Annual Economic Report, (2012), Issue: 20, p. 56. National Economic Development board. Planning and Decision Support Department, UAE. Available from: http://www.economy.ae.

[33] United Arab Emirates Monitor. Inflation: Recent Developments. Article, (2011), p. 9-10. Accession Number: 67422716.

[34] WAM Emirates News Agency. UAE's Goal of $1 \%$ Unemployment Requires Renewed Focus on $21^{\text {st }}$ Century Skills, (2015), Dubai, UAE. Available from: https:/www.wam.ae/en/news/emirates/1395276705339.html. 